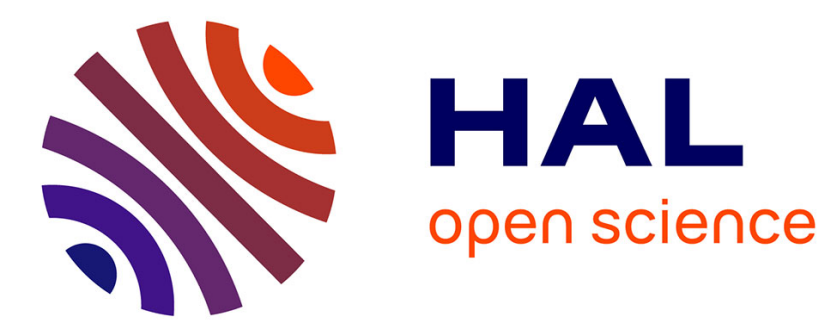

\title{
Short-term implantation effects of a DCPD-based calcium phosphate cement
}

Patrick Frayssinet, Laurent Gineste, Philippe Conte, Jacques Fages, Nicole Rouquet

\section{- To cite this version:}

Patrick Frayssinet, Laurent Gineste, Philippe Conte, Jacques Fages, Nicole Rouquet. Short-term implantation effects of a DCPD-based calcium phosphate cement. Biomaterials, 1998, 19 (11-12), pp.971-977. 10.1016/S0142-9612(97)00163-4 . hal-02352239

\section{HAL Id: hal-02352239 \\ https://hal.science/hal-02352239}

Submitted on 6 Nov 2019

HAL is a multi-disciplinary open access archive for the deposit and dissemination of scientific research documents, whether they are published or not. The documents may come from teaching and research institutions in France or abroad, or from public or private research centers.
L'archive ouverte pluridisciplinaire HAL, est destinée au dépôt et à la diffusion de documents scientifiques de niveau recherche, publiés ou non, émanant des établissements d'enseignement et de recherche français ou étrangers, des laboratoires publics ou privés. 


\title{
Short-term implantation effects of a DCPD-based calcium phosphate cement
}

\author{
Patrick Frayssinet $^{\mathrm{a}, \mathrm{d}, *}$, Laurent Gineste ${ }^{\mathrm{b}}$, Philippe Conte ${ }^{\mathrm{c}}$, \\ Jacques Fages ${ }^{\mathrm{d}}$, Nicole Rouquet ${ }^{\mathrm{d}}$ \\ ${ }^{a}$ Laboratoire du Tissu Osseux et des Pathologies Ostéoarticulaires, Université Paul Sabatier, Toulouse, France \\ ${ }^{\mathrm{b}}$ Ecole Dentaire, Université Paul Sabatier, 31400 Toulouse, France \\ ${ }^{\mathrm{c}}$ Service de Chirurgie Orthopédique, CHU Toulouse Purpan, Toulouse, France \\ ${ }^{\mathrm{d} B i o l a n d,} 132$ route d'Espagne, 31100 Toulouse, France
}

\begin{abstract}
Calcium phosphate cements can be handled in paste form and set in a wet medium after precipitation of calcium phosphate crystals in the implantation site. Depending on the products entering into the chemical reaction leading to the precipitation of calcium phosphates, different phases can be obtained with different mechanical properties, setting times and injectability. We tested a cement composed of a powder, containing $\beta$-tricalcium phosphate $(\beta$-TCP) and sodium pyrophosphate mixed with a solution of phosphoric and sulphuric acids. The cement set under a dicalcium phosphate dihydrate (DCPD)-based matrix containing $\beta$-TCP particles. This was injected with a syringe into a defect drilled in rabbit condyles, the control being an identical defect left empty in the opposite condyle. The condyles were analysed histologically 2, 6 and 18 weeks after implantation. After injection into the bone defect the cement set and formed a porous calcium phosphate structure. Two different calcium phosphate phases with different solubility rates could be identified by scanning electron microscopy (SEM) observation. The less-soluble fragments could be degraded by cell phagocytosis in cell compartments of low $\mathrm{pH}$ or integrated in the newly formed bone matrix. The degradation rate of the material was relatively high but compatible with the ingrowth of bone trabeculae within the resorbing material. The ossification process was different from the creeping substitution occurring at the ceramic contact. Bone did not form directly at the cement surface following the differentiation of osteoblasts at the material surface. The trabeculae came to the material surface from the edges of the implantation site. Bone formation in the implantation site was significantly higher than in the control region during the first week of implantation. In conclusion, this material set in situ was well tolerated, inducing a mild foreign-body reaction, which did not impair its replacement by newly formed bone within a few weeks.
\end{abstract}

Keywords: Calcium phosphate cements; Osseointegration; Biomaterial; Injectable

\section{Introduction}

Self-setting calcium phosphate cements are materials that can be handled by the surgeon in paste form and injected into bone cavities or defects. They then set to form a mineral matrix at the contact of which healing bone tissue can form. Replacement of the mineral by bone is supposed to occur as a result of the same process taking place at the calcium phosphate ceramic contact. These matrices result from the precipitation of a calcium

*Corresponding author. Tel.: 003356220 6290; fax: 003356220 0346 . phosphate phase different from the one in suspension in the paste. The strength of the cement is given by the entanglement of the growing mineral crystals. To obtain a calcium phosphate cement with mechanical properties compatible with surgical use, the raw material in solution must be able to dissolve and recrystallize properly.

Calcium phosphate cements were originally developed to act as osteoconductive materials able to take the exact shape of the cavity to be filled and injectable with a syringe without requiring an open way through the tissues. This concept is not new: plaster of Paris which consists of calcium sulphate was used in such a way by Dreesman in 1892 [1]. Brown and Chow [2] were the first to develop and patent a calcium orthophosphate cement. 
Numerous components can enter into the chemical reaction leading to calcium phosphate precipitation. Driessens and co-workers $[3,4]$ listed the different calcium phosphates that could be formed at temperatures close to room temperature and known to be biocompatible. More than 100 different formulations of calcium orthophosphate cements were subjected to determinations of the compressive strength and the diametral tensile strength after storage at room temperature for $24 \mathrm{~h}$ under $100 \%$ relative humidity. The setting occurred on more than 15 formulations. These cements could be divided into four classes: dicalcium phosphate dihydrate, calcium and magnesium phosphates, octocalcium phosphate and non-stoichiometric apatite cements.

Mirtchi et al. [5] developed an orthophosphate cement based on mixtures of monocalcium phosphate monohydrate $(\mathrm{MCPM})$ and $\beta$-tricalcium phosphate $(\beta$-TCP) with water.

We have developed a new calcium phosphate hydraulic cement that can set in a wet environment and be injected with a syringe into a bone defect or fracture site. The cement consists of a solid phase containing $\beta$-TCP and sodium pyrophosphate and a liquid phase composed of orthophosphoric and sulphuric acid. The setting reaction can be summarized as follows:

$\mathrm{Ca}_{3}\left(\mathrm{PO}_{4}\right)_{2}+\mathrm{H}_{3} \mathrm{PO}_{4}+6 \mathrm{H}_{2} \mathrm{O} \rightarrow 3 \mathrm{CaHPO}_{4} \cdot 2 \mathrm{H}_{2} \mathrm{O}$

This acid-base reaction can be divided into three stages: (1) tricalcium phosphate dissolution; (2) nucleation; (3) dicalcium phosphate growth. The physico-chemical properties of the cement can be modified by the purity and the granulometry of the tricalcium phosphate. Dicalcium phosphate is known to be one of the most soluble of calcium phosphate phases [6] and can be useful when material degradable within a few weeks is needed.

The aim of the described experiment was to check that the material set when injected by syringe into a bone cavity, and to examine the short-term effects of the material on the surrounding tissues.

\section{Materials and methods}

\subsection{Animals}

The animals used for experiments were nine female New Zealand white rabbits aged 6-7 months with body weights of $3700-5100 \mathrm{~g}$ and which had free access to food and water. The animals were observed daily for 1 week after implantation and three times a week for the remaining implantation period. The skin in the implanted region, animal mobility and behaviour were noted.

\subsection{Material injected}

Powder: $3 \mathrm{~g}$ ( $\beta$-TCP, $2.954 \mathrm{~g}$; anhydrous sodium pyrophosphate, $0.046 \mathrm{~g}$ ). Liquid: $1.8 \mathrm{ml}$ (phosphoric acid (4 M) and sulphuric acid $(0.1 \mathrm{M})$ solution). In this study, the powder/liquid ratio was 1.3 and the conversion rate $95 \%$. The resulting solid material consisted of $95 \%$ of dihydrated dicalcium phosphate (DCPD), $4 \%$ of $\beta$-TCP and $1 \%$ of various mineral phases (sodium based and calcium sulphate). The density was 1.43 , the porosity $45 \%$ and the mean pore diameter $7.1 \mu \mathrm{m}$.

\subsection{Injection of bone cement}

The cement was inserted under anaesthesia with intramuscular ketamine, through a lateral longitudinal skin incision over the knee, in holes drilled in the external condyles of rabbits. Holes were drilled in the external condyles of the right and left legs. The left hole was filled with the cement and the right hole was left empty as control.

Each hole was $4 \mathrm{~mm}$ in diameter and $5 \mathrm{~mm}$ in length. The cement was injected through a syringe in paste form as follows:

- the liquid phase was poured in a polyethylene bowl

- the solid phase was added to the liquid at $t=0$

- the mixture was blended with a spatula for $30 \mathrm{~s}$ to obtain a homogeneous mixture

- the cement was poured into a syringe and left to rest

- it was then injected into the cavity after about $4 \mathrm{~min}$

- the cement was left to set for 10 min without any further manipulation

Three animals were killed by nembutal injection after 2, 6 and 18 weeks and the distal extremities of the femurs were collected.

\subsection{Histological processing}

The samples were fixed in a $4 \%$ formaldehyde solution for $48 \mathrm{~h}$, dehydrated in increasing ethanol solution then embedded in poly(methyl methacrylate (PMMA)). Sections $5-\mu \mathrm{m}$ thick were obtained with a hard tissue microtome (Reichert-Jung Type E). They were then stained with Giemsa solution and by the Von Kossa method.

The remaining histological blocks were gold/palladium-coated and observed by scanning electron microscopy (SEM) under a back-scattered mode operated at $10 \mathrm{kV}$.

Qualitative and quantitative studies were performed on the longitudinal histological sections made through the cylinder centre. The histomorphometry measurements were obtained on an equal surface for each section. The measurement zones were centred either on the middle of the implant or the middle of the control zone. The measurements were carried out on the entire implant or control site on each section. Three sections were located very close to the cylinder centre (less than $100 \mu \mathrm{m})$. Five primary measurements were taken to 
characterize the structure of the newly formed bone at the implanted site:

- Trabecular bone surface was defined as the bone surface to total tissue surface ratio (BS/TS). The bone surface comprised the mineralized and the osteoid surfaces. The total tissue surface consisted of the bone surface, bone marrow, stromal tissue and the calcium phosphate implant.

- The relative osteoid surface (OS/BS) measures the percentage of the trabecular bone surface that is osteoid.

- The active osteoid surface Ob.S/BS measures the percentage of trabecular surface lined by osteoblasts.

- The relative eroded surface (ES/BS) measures the percentage of trabecular surface eroded by osteoclasts.

We defined another parameter that, unlike the previous, was not in the report of the ASBMR histomorphometry nomenclature committee [7], the implant surface (IS/TS). The measures were obtained using a computerized image analysis device coupled to a Reicher Polyvar microscope.

\subsection{Statistical analysis}

The measures were obtained on three sections for each implanted site. Statistical analyses were carried out according to a two-way analysis of variance (ANOVA) test.

\section{Results}

\subsection{Qualitative histology}

\subsubsection{After 2 weeks}

The implantation zone was occupied by a solid cylinder made of mineral grains that had been partly removed from the section by the microtome blade. Thin newlyformed trabeculae originating from the cortical zone were inserted perpendicularly to the implant surface. These trabeculae were surrounded by an osteoid layer lined with active osteoblasts. Bone marrow cavities between these trabeculae were filled with connective tissue containing many fibroblast-like cells and bone trabeculae fragments (Figs. 1 and 2). No haematopoietic cell could be found in these bone marrow cavities at this time.

Some cell condensations at the origin of connective tissue trabeculae could be seen in the vicinity of the implant, some of which were synthesizing an extracellular matrix (ECM) undergoing mineralization. Resorption marks were apparent at the implant surface into which the tissue had grown.

In one sample, the inner part of the cylinder was surrounded by a thin layer of cellular connective tissue (Fig. 3).

A few mineral grains had become detached from the implants and were found free in the connective tissue in the bone marrow cavities or even included within the

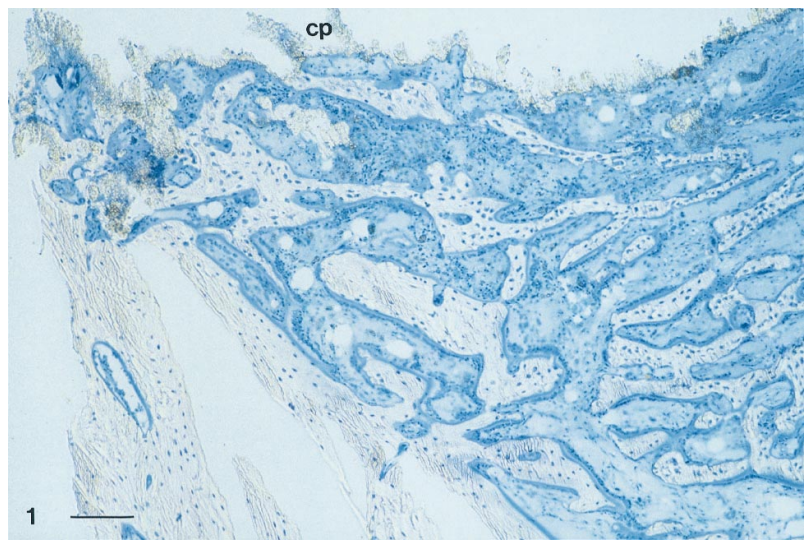

Fig. 1. Subperiosteal region of the cylinder (cp) in contact with newly formed bone trabeculae 2 weeks after implantation. The material was removed from the section by the microtome blade. Bar $=300 \mu \mathrm{m}$.

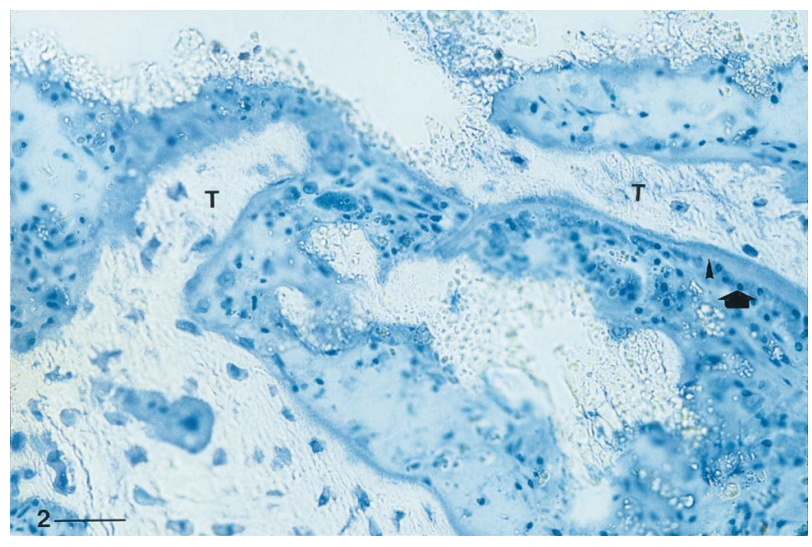

Fig. 2. Interface bone-material on the same section as in Fig. 1. Bone trabeculae (T) are apposed at the material surface and coated with osteoid tissue $(\rightarrow)$ lined with osteoblasts $(\rightarrow)$. Grains of material are found in the bone marrow cavity. Bar $=100 \mu \mathrm{m}$.

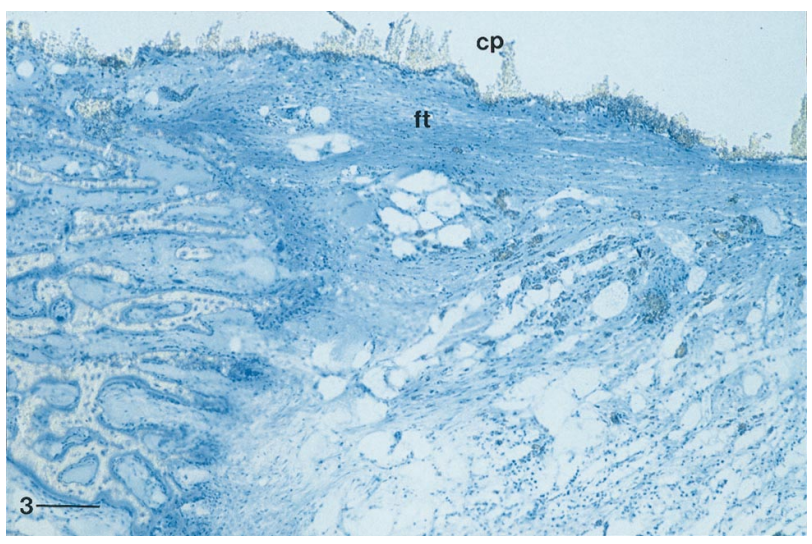

Fig. 3. Tissue-material interface in the mid-region of the same implant (cp) as in Fig. 1. The external part is in contact with newly formed bone tissue while the inner part is surrounded by dense connective tissue (ft) with collagen bundles parallel to the material surface. $\mathrm{Bar}=300 \mu \mathrm{m}$. 
bone matrix. Some of them had been phagocytosed into macrophages. These grains were round in shape and did not exceed $12 \mu \mathrm{m}$ in size.

SEM showed that the material consisted of small white particles disseminated within a grey matrix with some micropores. Several grey-levels were visible in the matrix suggesting an unhomogeneous setting (Figs. 4-6).

The control bone defect was filled with loose connective tissue in the form of a network with connective tissue trabeculae several tens of a micrometre in thickness. Ossification had begun at the edges of the defect.

\subsubsection{After 6 weeks}

One implant was almost degraded, with some fragments of a few hundred micrometres present and surrounded by immature bone trabeculae and unmineralized osteoid tissue (Figs. 7-9). The amount and localization of this osteoid was unusual. Some calcium phosphate particles were found within the periosteum. A hyperplasic reaction of the periosteum had occurred. However, around these particles, no macrophage was evidenced.

Other implants showed a mineral core which still appeared as a solid. The region beneath the cylinder surface had been invaded by bone trabeculae. The bone marrow cavities between the trabeculae were completely filled with implant fragments. These fragments embedded within the bone tissue contained cells between the crystals. The bone trabeculae structure was immature with many remodelling marks. An organic matrix was visible in some sites at the implant surface. Many grains detached from the material were phagocytosed by macrophages and gaint cells.

SEM revealed the presence of material fragments far from the implantation zone in the condyle. A dissolution zone of thickness 100 to $300 \mu \mathrm{m}$ could be observed under the material surface in one implant. Mineralizing bone trabeculae were ingrowing in this zone. The material core lined by this dissolution zone was edged by a densified layer less than $100-\mu \mathrm{m}$ thick (Fig. 10).

The control defects were occupied by low-density trabecular bone in which the bone marrow cavities contained cytologically normal marrow.

\subsubsection{After 18 weeks}

Small grains emitted by the material were less numerous in the bone marrow cavities surrounding the fragmented materials. The remaining implants were fragmented with two or three big fragments totally lined by bone trabeculae parallel to the fragment surfaces. This lining bone layer was linked to the cortical bone by bone trabeculae.

The SEM showed that the material was a solid with pores ranging from a few to a hundred micrometres. White grains of different sizes ranging from one or two to several tens of micrometres were dispersed within a grey

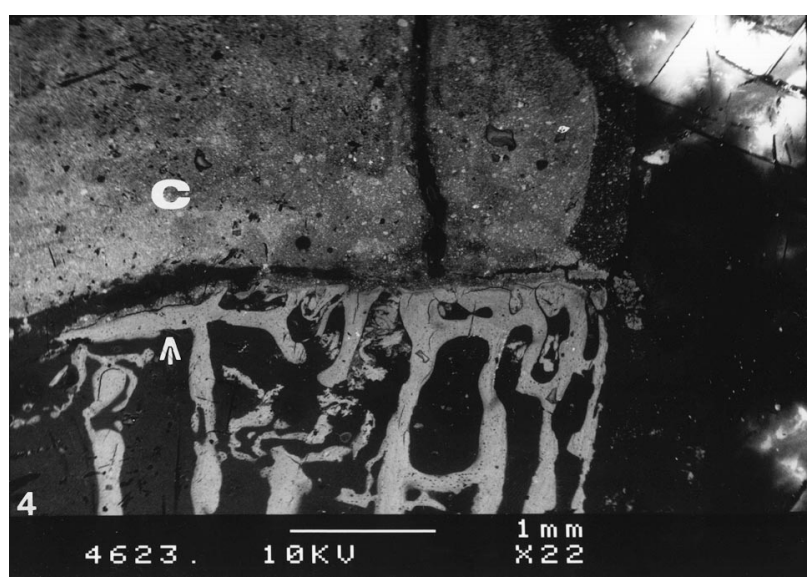

Fig. 4. Backscattered SEM of a 2-week implanted cement (C). Very immature bone trabeculae $(\rightarrow)$ and bone fragments are in contact with the implant surface. The implant shows different grey levels due to different densities suggesting that the cement did not set homogeneously after implantation. Some implant fragments are detached from the surface. Bar $=1 \mathrm{~mm}$.

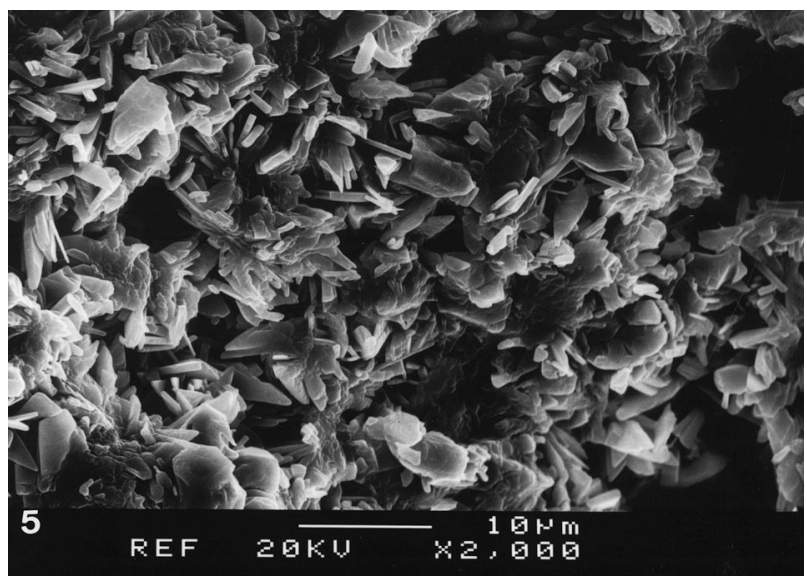

Fig. 5. SEM of the section surface of an implant after 2 weeks showing interconnected crystals with pores within the matrix. Bar $=10 \mu \mathrm{m}$.

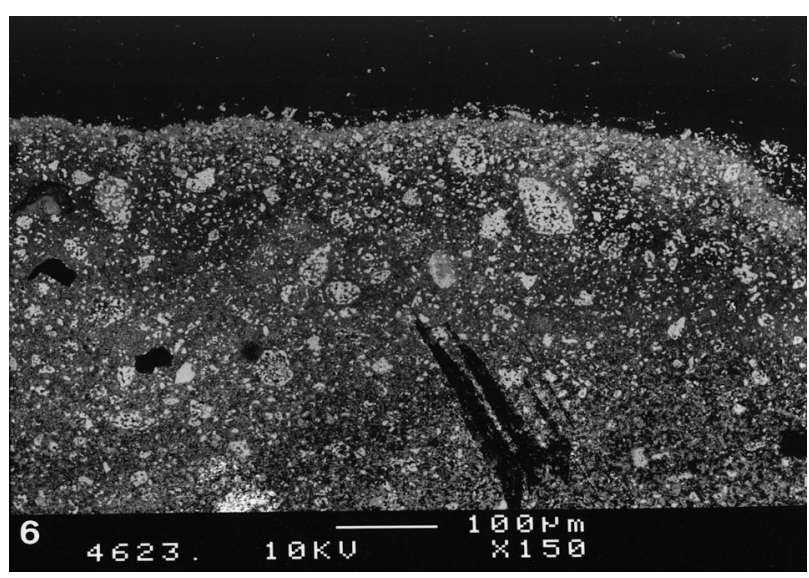

Fig. 6. Backscattered SEM of the section of a 2-week implanted cement showing white particles identified as $\beta$-TCP disseminated within a grey matrix with irregular porosity identified as DCPD. Bar $=100 \mu \mathrm{m}$. 


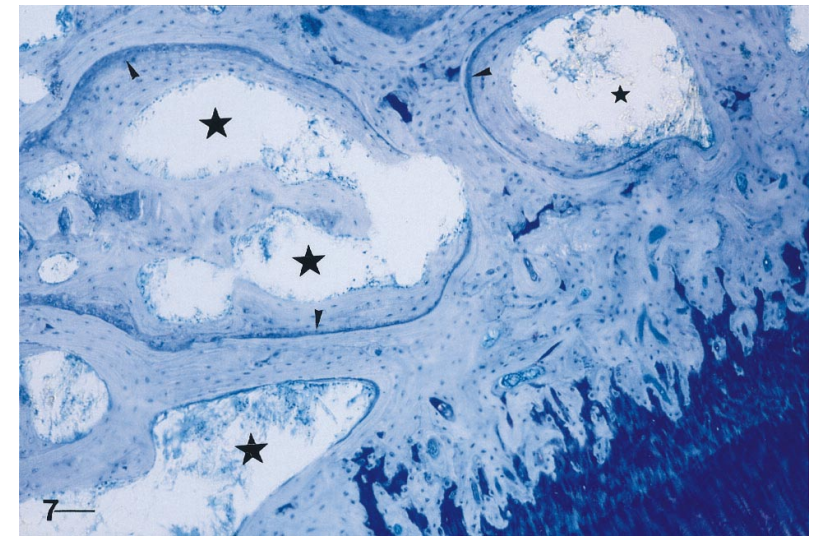

Fig. 7. Fragments of a 6 -week implanted cylinder $(\star)$ separated by bone trabeculae showing cemented lines ( ) probably indicating the start of the growth period. Bar $=200 \mu \mathrm{m}$.

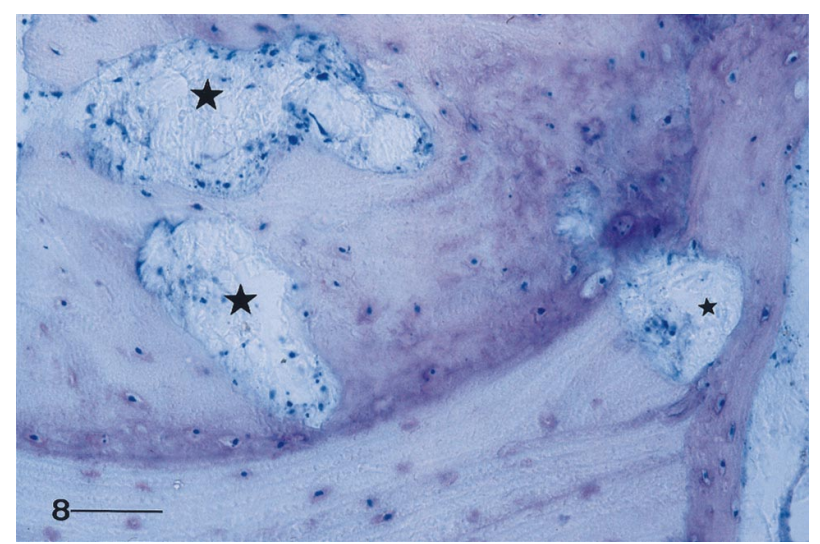

Fig. 8. Implant fragments $(\star)$ embedded within immature bone 6 weeks after implantation. Most of the fragment volume contains cells whose nuclei are visible (blue dots). Bar $=250 \mu \mathrm{m}$.

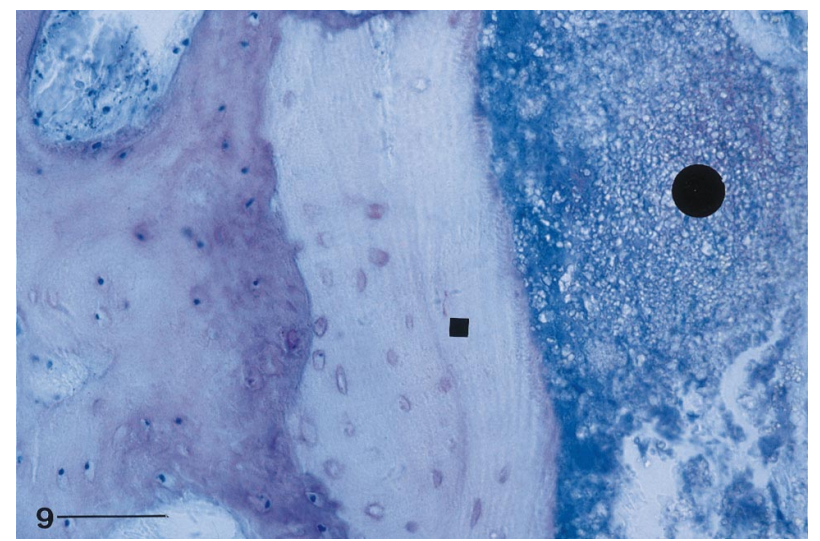

Fig. 9. High magnification of the interface between the bone ( $\boldsymbol{\square})$ and the mineral matrix $(\bullet)$. An organic matrix has invaded the matrix porosity. The grains are dissociated and the matrix is not mineralized. Bar $=250 \mu \mathrm{m}$.

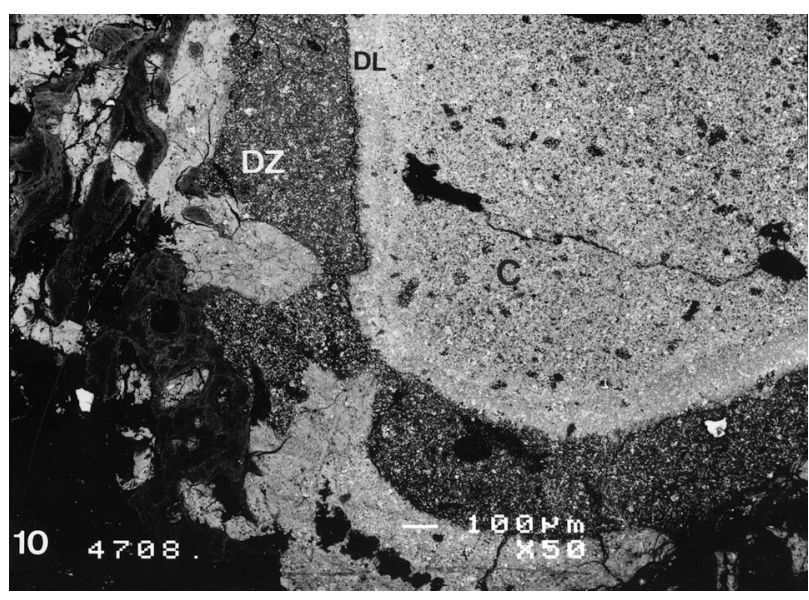

Fig. 10. Backscattered SEM of the dissolution zone (DZ) principally affecting the DCPD matrix beneath its surface. The core of the cylinder (C) is lined with a densified layer (DL) of material. Bar $=100 \mu \mathrm{m}$.

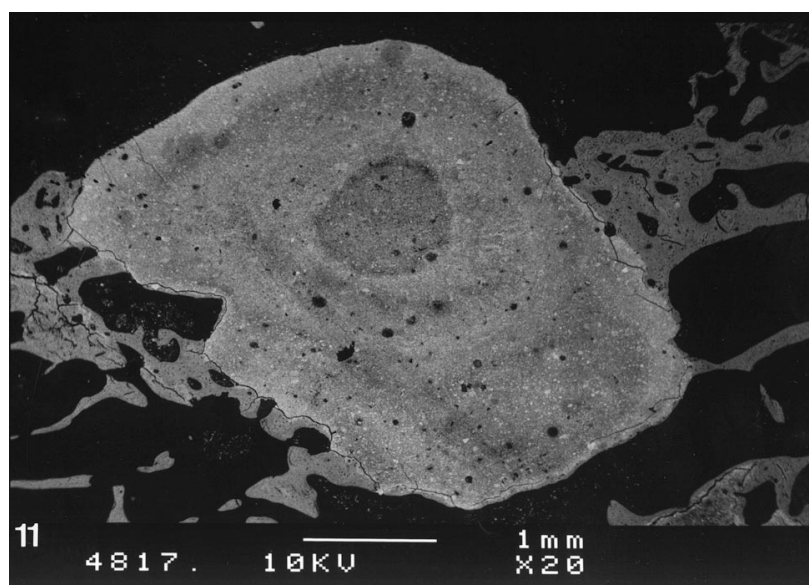

Fig. 11. Backscattered SEM of a fragment of an 18-week implanted cylinder of microporous structure on which bone trabeculae are apposed. $\mathrm{Bar}=1 \mathrm{~mm}$.

matrix (Figs. 11 and 12). Bone matrix showing different grey levels was in contact with the material. Some white particles could be found in the Havers canals and were probably grouped within the histiocytes. Some such particles were included within the bone matrix.

The control zones were difficult to differentiate from the rest of the bone tissue. However, the low density of trabeculae in this region was characteristic of the control zone.

\subsection{Histomorphometry}

As shown by the implant surface (IS) measurements, the implant degraded during the implantation time Table 1. One quarter of the implant surface section remained after 18 weeks. During the first 6 weeks of implantation, there was a significant increase in the amount of bone trabeculae in the sites implanted with the cement 


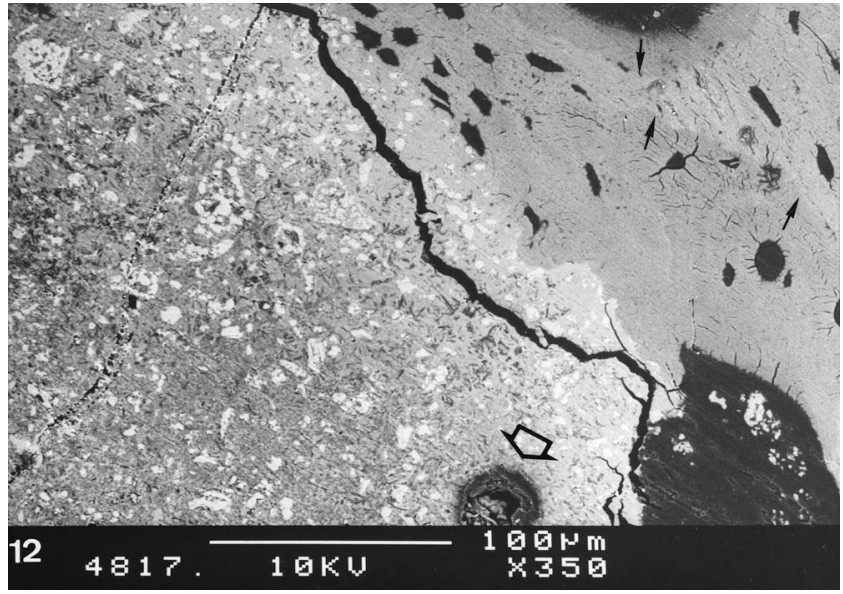

Fig. 12. Higher magnification of the bone-material interface observed by backscattered SEM 18 weeks after implantation. Some degradation marks $(\Rightarrow)$ are visible at the material surface. The bone matrix shows different grey levels with the light grey zone having a very high cellularity characteristic of immature bone suggesting the occurrence of bone matrix ( ) maturation. Bar $=100 \mu \mathrm{m}$.

compared to the control sites. At 6 weeks, bone formation as indicated by the active osteoid surface (AOS) and relative osteoid surface (ROS) measurements was still significantly higher in the sites implanted with cements than in the control sites.

\section{Discussion}

This study showed that:

- The cement set when injected into a bone marrow cavity and formed a porous calcium phosphate structure.

- Two different calcium phosphate phases with different solubility rates could be identified by SEM observation. The small white granules disseminated in the matrix were probably made of $\beta$-TCP granules because the density (TCP $=3.14$ ) was higher than that of
DCPD (2.83). Furthermore the difference was increased by the TCP sintering during powder manufacture.

- A mild foreign-body reaction occurred in the vicinity of the material with a majority of mononucleated cells. Calcium phosphate particles were phagocytosed in these cells.

- The degradation rate of the material was relatively high when compared to the usual hydroxyapatite (HA) and TCP ceramics but compatible with the ingrowth of bone-forming trabeculae within the resorbing material.

Different fast-setting calcium phosphates have been described [3, 4, 8, 9-12] that all show osteoconductive properties and can be injected. These cements are generally the product of an acid-base reaction. The reaction $\mathrm{pH}$, which was not measured in this experiment, has proved to be low in vitro and did not seem to induce any necrosis as no dead tissue zone was visible 2 weeks after implantation. Ohura et al. [13] described the implantation of a DCPD-based cement obtained from a mixture of MCPM (monocalcium phosphate monohydrated) and $\beta$-TCP to which calcium sulphate hemihydrate had been added. The samples were set during the intervention outside the body and implanted when solid. They concluded that these cements stimulated bone formation and were rapidly integrated by bone tissue.

In this experiment, the dissolution products induced a low foreign-body reaction. However, the presence of macrophages and gaint cells in the implantation site did not impair bone formation within the same site. Some differentiating osteoblasts synthesizing an osteoid matrix were identified among the macrophages. No increase in bone resorption could be detected at any time.

The ossification process occurring at the material contact was not identical to that taking place at the contact of calcium phosphate ceramics. Osteoblast differentiation preferentially occurs at the calcium phosphate ceramic surface and leads to the presence of an osteoblast line which synthesizes an osteoid matrix and then an

Table 1

Histomorphometric measurements made on the different sections expressed as a percentage

\begin{tabular}{|c|c|c|c|c|c|c|c|c|c|c|}
\hline \multirow{2}{*}{$\begin{array}{l}\text { Implantation time } \\
\text { (weeks) }\end{array}$} & \multicolumn{2}{|l|}{ TBS } & \multicolumn{2}{|l|}{ IS } & \multicolumn{2}{|l|}{ AOS } & \multicolumn{2}{|l|}{ ROS } & \multicolumn{2}{|l|}{ RES } \\
\hline & Implant & Control & Implant & Control & Implant & Control & Implant & Control & Implant & Control \\
\hline 6 & $\begin{array}{l}31.4 \\
(11.12)\end{array}$ & $\begin{array}{c}21.87 \\
(7.33)\end{array}$ & $\begin{array}{c}31.83 \\
(15.27)\end{array}$ & 0 & $\begin{array}{l}11.66 \\
(11.32)\end{array}$ & $<1$ & $\begin{array}{c}7.25 \\
(0.25)\end{array}$ & $<1$ & 0 & 0 \\
\hline
\end{tabular}

Abbreviations: TBS, trabecular bone surface (BS/TS); IS, implant surface (IS/TS); AOS, active osteoid surface (Ob.S/BS); ROS, relative osteoid surface (OS/BS); RES, relative eroded surface (ES/BS).

Mean values with standard deviation in parentheses. 
immature bone. Once the material surface has been coated by an immature bone layer, the bone then extends to the entire pore volume.

In contrast, osteoblasts are not, or very rarely, found at the cement surface. Most of the osteoblasts differentiate at some distance from the cement and there is ingrowth of the forming bone trabeculae from the implantation cavity edges into the spaces made available by material resorption. An interposition of a metachromatic matrix between some trabeculae and the cement during the early stages of implantation is in agreement with trabecular ingrowth.

It is difficult to explain such differences in the ossification process. The high surface area of the material associated with the high solubility of the matrix could induce a microenvironment with a different physico-chemistry from that of the ceramic. The instability of the resorbing surface of the material could also have a role in these differences. The resorption could be too fast to allow bone apposition at the material surface.

\section{Conclusions}

This formulation gives a fast-setting calcium phosphate showing ability to be replaced by bone tissue although a foreign-body reaction was detected. Setting was effective in a wet environment and particularly in bone. The degradation rate of the material was compatible with ingrowth of the bone tissue within the degrading cement. The cylinders were degraded within a matter of weeks making it possible to use this matrix as a carrier for molecules under such physico-chemical setting conditions. The ossification process which took place at the material contact was different from that occurring at the ceramic contact.

\section{References}

[1] Dreesman H. Uber Knochenplombierung Beitre. Klin Chir 1892; 9:804-807.
[2] Brown W, Chow LC. Combinations of sparingly soluble calcium phosphates in slurries and paste as mineralizers and cements. US Patent No. 4612053, 1986.

[3] Driessens FCM, Boltong MG, Bermudez O, Planell JA. Formulation and setting times of some calcium orthophosphate cements: a pilot study. J Mater Sci: Mater Med 1993;4:503-508.

[4] Driessens FCM, Boltong MG, Bermudez O, Planell JA, Ginebra MP, Fernandez E. Effective formulations for the preparation of calcium phosphate bone cements. J Mater Sci: Mater Med 1994;5:164-170.

[5] Mirtchi AA, Lemaïre J, Munting E. Calcium phosphate cements action of setting regulators on the properties of the $\beta$-tricalcium phosphate-monocalcium phosphate cements. Biomaterials 1989; 10:634-39.

[6] Nancollas H. In vitro studies of calcium phosphate crystallisation. In: Mann S, Webb J, Williams RJP, editors. Biomineralization. Chemical and biochemical perspectives. New York: VCH, 1989:157-182.

[7] Parfitt AM, Drezner MK, Glorieux FH et al. Bone histomorphometry: standardization of nomenclature, symbols and units. Report of the ASBMR nomenclature committee. J Bone Miner Res 1987;2:595-610.

[8] Ishikawa K, Takagi S, Chow LC, Ishikawa Y. Properties and mechanisms of fast-setting calcium phosphate cements. J Mater Sci: Mater Med 1996;17:1429-32.

[9] Kurashina K, Kurita H, Hirano M, de Blieck JMA, Klein CPAT, de Groot K. Calcium Phosphate cement: in vitro and in vivo studies of the $\alpha$-tricalcium phosphate-dicalcium phosphate dibasic-tetracalcium phosphate monoxide system. J Mater Sci: Mater Med 1995;6:343-47.

[10] Constanz BR, Ison IC, Fulmer MT et al. Skeletal repair by in situ formation of the mineral phase of bone. Science 1995; 267:1796-99.

[11] Bermudez O, Boltong MG, Driessens FCM, Planell JA. Development of some calcium phosphate cements from combination of $\alpha$-TCP, MCPM and CaO. J Mater Sci: Mater Med 1994; 5:160-63.

[12] Miyamato Y, Ishikawa K, Fukao $\mathrm{H}$ et al. In vivo setting behaviour of fast-setting calcium phosphate cement. Biomaterials 1995; 16:855-60.

[13] Ohura K, Bohner M, Hardouin P, Lemaitre J, Pasquier G, Flautre B. Resorption of, and bone formation from, new $\beta$-tricalcium phosphate-monocalcium phosphate cements: an in vivo study. J Biomed Mater Res 1996;30:193-200.

[14] Frayssinet P, Trouillet JL, Rouquet N, Azimus E, Autefage A. Osseointegration of macroporous calcium phosphate ceramics having a different chemical composition Biomaterials 1993; $14: 423-29$. 